\title{
Facilitating Servitization in Manufacturing Firms: The Influence of Strategic Orientation
}

\author{
Yu Zhang ${ }^{1}$, Yajuan Wang ${ }^{2, *}$ and Yao Li $^{3}$ \\ 1 Business School, Hohai University, Nanjing 211100, China; yuyuzhang88@sina.com \\ 2 International Business School, Shaanxi Normal University, Xi'an 710119, China \\ 3 School of Management, Tianjin University of Technology, Tianjin 300382, China; goodluckly75@163.com \\ * Correspondence: wyj@snnu.edu.cn
}

Citation: Zhang, Y.; Wang, Y.; Li, Y. Facilitating Servitization in Manufacturing Firms: The Influence of Strategic Orientation. Sustainability 2021, 13, 13541. https://doi.org/ $10.3390 /$ su132413541

Academic Editor: Ermanno C. Tortia

Received: 4 October 2021

Accepted: 2 December 2021

Published: 7 December 2021

Publisher's Note: MDPI stays neutral with regard to jurisdictional claims in published maps and institutional affiliations.

Copyright: (c) 2021 by the authors. Licensee MDPI, Basel, Switzerland. This article is an open access article distributed under the terms and conditions of the Creative Commons Attribution (CC BY) license (https:// creativecommons.org/licenses/by/ $4.0 /)$.

\begin{abstract}
Servitization has significant implications for the sustainable development of manufacturing, the economy, and the environment. However, it does not always produce returns as the firms expect, which may discourage them from engaging in this transition. In this study, we examine the facilitating effects of two dimensions of strategic orientation (i.e., technology and market orientation) on two types of servitization (i.e., basic and advanced service provision), and further investigate the performance impacts of these servitization types contingent on firm size. By conducting an empirical study, using survey data comprising 210 samples, we confirm that both technology and market orientation are positively related to basic and advanced service provision. Moreover, while they have equal effects on basic services, market orientation is more important than technology orientation for providing advanced services. We also find that, for basic services, these two strategic orientations function independently, whereas they reinforce each other in the provision of advanced services. Finally, the relationship between servitization and firm performance is contingent on the size of the firm. Our results show that small firms can benefit from providing basic services, rather than advanced services, while only advanced services can improve the performance of large firms further.
\end{abstract}

Keywords: servitization; strategic orientation; firm performance; firm size

\section{Introduction}

As a response to increased competition and decreased profit margins in the manufacturing sector, manufacturers have been increasingly supplementing products with value-added services so as to differentiate their products and simultaneously generate an additional revenue stream [1-4]. This trend of servitization, firstly identified by Vandermerwe and Rada in the late 1980s [5], has become a critical source of sustainability, contributing significantly to the long-term development of firms [6-8], a resource-efficient circular economy [9], and a healthy environment [10]. Following Baines et al., we refer to servitization in this paper as the innovation of an organization's capabilities and processes to shift from selling products to selling integrated products and services that deliver value in use [4]. The purported benefits of this innovation, such as the enhanced value of physical products, increased pricing power, improved customer loyalty, and higher-value business potential $[4,7,8,11,12]$, have motivated many manufacturers, not only large firms, but also small- and medium-sized enterprises, to reorient themselves toward services [13,14].

However, the phenomenon of the "servitization paradox" stands in the way of successful servitization for manufacturers [15]. While it is widely recognized that servitization delivers ambitious growth and profitability objectives [16,17], there is still a number of research suggesting that it is not readily achievable for servitized firms to realize those promised benefits $[1,2,12,18]$. Sometimes the servitization efforts may even result in lower revenues or net profits, compared to pure product-manufacturing firms [2,19]. Therefore, further insights into the key success factors for servitization, and the possible ways of managing it effectively to achieve a rewarding performance, are needed. 
One of the reasons behind the "servitization paradox" is that the transition from a product-centered business to a service-centered mindset and logic is not smooth, since it entails a wide array of changes in the firm's business models and value-generating mechanisms $[20,21]$, such as a redeployment and reconfiguration of a firm's resource base and organizational capabilities and structures, a redefinition of the mission of the firm, a revamping of routines and the shared norms and values [20,22], and even a professional value co-creation within and outside the firm [23], which would present risks and challenges and may meet resistance throughout the firm $[1,8,13,15]$. Therefore, support and guidance, from a strategic perspective, are needed first and foremost for this transformation to proceed $[22,24]$. However, prior works have focused more on operational-level drivers of servitization, such as organizational structures and processes [25], specific capabilities [26,27], and supply-chain integration [3], and the role of strategic-level enablers, by and large, remains understudied. Based on the strategic choice theory, we suggest that a strategic orientation which reflects the strategic direction implemented by firms to guide them in creating appropriate behaviors for superior long-term performance [24,28-30] has the potential to help the firms through those challenges and to facilitate their servitization transformation [23].

Moreover, with a few exceptions, servitization is generally studied as homogeneous in previous research. Services offered by manufacturing firms take on various forms, ranging from an addition to a basic product or sales process to a constituent of an integrated solution [31,32]. As these services differ substantially in regard to their requirements, level of risk, and potential of creating competitive advantages $[7,12,33]$, treating them as an undifferentiated mixture would make it difficult to profit from servitization. On the one hand, implementing different types of services may require support from different antecedents, such as diverse dimensions of strategic orientation that guide the firm's resource allocation $[34,35]$. Thus, the alignment between them merits serious consideration. On the other hand, the performance outcomes of servitization might be dependent on the types of services and contextual factors $[2,17,18]$. Managers need to figure out how certain types of services might lead to performance in specific contexts, such as in organizations characterized by varying sizes, which, however, is understudied in the recent research. Therefore, recent research has called for the future exploration of the contingency framework that explains which challenges are likely to be faced and which capabilities and actions are suitable with a certain type of servitization, to gain a deeper understanding of servitization transformation [36].

To address these research gaps, this study draws on the strategic choice theory and servitization literature to develop a model linking strategic-level antecedents, servitization, and firm performance. Our objective is to explore the impacts of the diverse dimensions of strategic orientation on different types of service provision, as well as the performance implications of these services that are contingent on organizational characteristics. Some interesting results are obtained through theoretical arguments and empirical tests. Specifically, we classify servitization into two categories based on the type of service offerings, namely, basic services (BAS) and advanced services (ADS), and find that both technology orientation ( $\mathrm{TO}$ ) and market orientation (MO), two prominent strategic orientations, are positively related to them. Moreover, while these two strategic orientations have equal effects on BAS, MO is more important than TO in providing ADS. Additionally, we find evidence about the individual roles of $\mathrm{TO}$ and $\mathrm{MO}$ in facilitating BAS, as well as the complementary relationship between them in enabling ADS. As for the effects of servitization on firm performance, our results show that it is contingent on the size of the firm, in that small firms can benefit from BAS, rather than ADS, while for large firms, only ADS can help to improve their performance further.

By doing so, we contribute to the current literature in three ways. First, we respond to the call for a contingency framework of servitization by differentiating between different types of service provision when exploring its antecedents and performance [36]. Second, we provide evidence as to the importance of strategic-level enablers in servitization. We 
also find a match patten between strategic orientation dimensions and servitization types, contributing to the debate about the relative importance of technology-focused mindsets and market-oriented mindsets in servitized manufacturers [20,37]. Third, we explore the effects of different types of servitization contingent on specific firm characteristics, explaining the variations observed in performance effects of servitization to some extent.

The remainder of this paper is structured as follows. Section 2 reviews the relevant literature and proposes specific hypotheses. Section 3 describes the methodology. Section 4 presents the empirical analyses and results. Section 5 discusses our findings, and outlines their potential theoretical contributions and managerial implications. Section 6 briefly highlights the essential conclusions, and identifies limitations and avenues for future research.

\section{Theory and Hypotheses}

\subsection{Servitization of Manufacturing Firms}

Manufacturing firms servitize by developing service offerings that extend beyond their traditional core product offerings [18]. There are a variety of services that can be offered during this transition process. Because of the heterogeneity in the nature of different service types, it is necessary to differentiate servitization in order to manage it effectively $[16,26,38]$. Many classification schemes have been suggested from various perspectives $[2,7,15,39]$. Following Sousa and da Silveira [26], we categorize servitization based on the types of services offered by manufacturers. These services are either product-centered (basic services, hereafter abbreviated as BAS) or customer-oriented (advanced services, hereafter abbreviated as ADS), which are associated with different value co-creation processes [38].

Specifically, the value proposition of BAS is to guarantee the proper access or functioning of the products or extend the life cycle of the products [26]. Examples include product maintenance and repair, installation and implementation, and spare parts management $[3,40,41]$. These services are transactional, characterized by low customization and limited interactions with the customers [26,33,39]. In contrast, ADS are more intricate and professional, which involve co-creating value with customers beyond basic product operation in the customer-specific context, typically including help desks or other customer supports, customer training, business consultancy, product adaptations to a customer's needs, and process operations on the customers' behalf [7,40,42]. These services are somewhat relational, characterized by high customization and intense interactions with the customers [38,42].

Studies have argued that BAS and ADS differ significantly regarding the critical resources and capabilities they require, as well as the risks and advantages they bring; therefore, servitized manufacturers should develop desired capabilities and implement the right organization according to the chosen offering $[18,26,43]$. Thus, it is reasonable to categorize servitization when exploring its exclusive enablers and performance effects.

\subsection{Strategic Orientation}

With the growing importance of servitization, many studies have focused on exploring the factors that would affect the transition to servitization [3,25-27]. The factors that have been identified are mainly operational-level drivers, yet the discussion about the role of strategic-level factors in servitization remains insufficient. This is a significant research gap, since the shift toward servitization does require the manufacturers' strategic intent to confront uncertainties and challenges, and to guide their specific conducts [44].

Accordingly, we rely on strategic choice theory to propose that the strategic orientation in organizations represents a strong organizational ideology and may provide strong reasons for their strategic choice of service provision [44]. Strategic orientation captures the firms' "broad strategic choices and directions implemented" ([28], p. 967) and has been confirmed to be able to affect the firms' capability to find new ways of creating value and innovating business models [29]. It sets a normative frame for how to conduct business competitively and which strategy to use [29], that is, whether and how to servitize. Therefore, it is important to examine the extent to which strategic orientation may enable 
or hinder servitization. Aligning the strategic orientation with servitization is essential for the success of servitization.

Previous research has identified various strategic orientation dimensions and shown that the firms' concrete strategic decisions differ due to their dominant strategic orientation [24]. Certain dimensions of strategic orientation, such as customer-orientation, are discussed implicitly in the context of servitization $[5,37,43]$. Based on these works and the strategic orientation literature, we make an initial attempt to formally link two prominent strategic orientations, i.e., technology and market orientation, to servitization in an integrated model. Technology orientation (TO) is defined as "the ability and the will to acquire a substantial technological background and use it in the development of new products" ([29], p. 78). Highly technology-oriented firms would place heavy emphasis on generating new ideas or adopting new methods and advanced technologies [45], which would exert impact on ways of value creation. Market orientation (MO) refers to efforts to acquire, disseminate and respond to intelligence about target customers and competitors throughout a firm [24,30]. With insights of the market conditions from MO, the firm can improve its innovative competence to take advantage of the market opportunities [46,47]. In sum, TO and MO deepen the firms' market and technology knowledge [24], which could be deployed by manufacturers that enter the service market to support their transformation. Thus, they are a suitable focus for research in the servitization context. For example, the roles of front-end technological tools, such as IoT, cloud computing, big data, and data analytics, as well as the need for customer contacts in service-business expansions, have been noted and confirmed in recent research $[8,23,48]$.

\subsection{Strategic Orientation and Servitization}

Technology orientation increases an organization's openness to new ideas and its propensity to adopt new technologies [34,49]. We submit that highly technology-oriented manufacturers are in privileged positions to offer both BAS and ADS, as they tend to leverage the technological knowledge accrued in the product domain to develop service extensions.

First, BAS require the provider to be equipped with manufacturing-based capabilities, namely, special knowledge about product design, its technology, and product/process engineering [26,43]. For example, maintenance or repair services require access to detailed documentation for the piece of equipment and benefit from detailed knowledge of the technical strengths and weaknesses of the design, and fabricating spare parts requires specialized production technologies $[38,50]$. Technical expertise and credibility are key for the customers to buy product-based services [43]. The expertise accrued through TO can be deployed to enable the firm to provide technical product support services to customers $[38,43,50]$. Moreover, with more refined technologies, TO could better motivate the firm to innovate its ways of ensuring the appropriate functioning of the products.

Second, TO entails a constant monitoring of technological developments and a constant search for new technologies beyond current products and market boundaries [29]. Hence, a technology-oriented firm maintains a focus on the development of highly innovative and technology-intensive products. BAS provision is more favored for these kinds of product because of the technical interdependency between them $[38,51]$, such as the access to unique spare parts and technical assistance during use, leading the customers to perceive a higher value differential in buying an integrated product-BAS bundle from the manufacturers [17]. Thus, we propose:

Hypothesis 1a (H1a). Technology orientation has a positive effect on basic service provision.

Compared to BAS, ADS are more sophisticated and require direct and rich interactions with customers [38]. We argue that TO could also facilitate the provision of ADS. First, ADS require the ability to design services and products jointly [26,43,52]. Manufacturers that aspire to offer ADS need to exploit the connections between products and services to generate new and synergistic resource combinations [1]. TO is critical for maintaining a culture that supports the exploration of highly innovative integrated solutions. Further- 
more, the characteristics of ADS suggest that they are typically tailored to the customers' contexts and needs [43]. Thus, they require strong product expertise and process application skills. Second, from the customers' perspectives, they would have more trust in firms that are advanced in technology and be more willing to work with these firms to explore the opportunities for ADS [38]. Thus, we propose:

Hypothesis $\mathbf{1 b}(\mathbf{H 1 b})$. Technology orientation has a positive effect on advanced service provision.

MO explains the adaptation of firms to their market environment in order to build competitive advantages [53]. Narver and Slater [30] proposed that MO is constituted of three dimensions: customer orientation, competitor orientation, and inter-functional coordination, representing the way in which a firm focuses on and responds to customers and competitors at a firm-wide (inter-functional) level. We argue that MO could enable the manufacturer to provide more services, both BAS and ADS. Market knowledge and strong customer bonds act as strategic resources for service offerings, and the firm's marketorientation practices would contribute to the development of these resources. MO leads the firm to identify, develop, and leverage market intelligence to reinvigorate its product portfolio and thereby adapt its offerings to customer needs for competitiveness $[30,53,54]$.

First, a focus on competitors could propel or inspire the firm to explore new ideas and introduce new value offerings to the market [49]. Both value-added services around products and hybrid offerings co-created with customers have the potential to boost competitiveness, and would thus be preferred by competitor-oriented firms.

Second, customer orientation is essential in the context of servitization, as the customer is the core component of a servitized manufacturer $[55,56]$. In fact, the service part of the hybrid offering is co-produced by the firm and the customer [3,57]. Customer orientation emphasizes the incorporation of the "customer's voice" and encourages interactions with the customer, leading to a deep understanding of the customer's business and how he intends to create value by using the product [37,38]. Such an understanding is crucial for ensuring the functionality of the product in the customer's operations and even the advanced services that cater to the customer's specific needs [26,52]. In addition, closer customer relationships could help in the production of servitized offerings by mitigating complexity and uncertainty emerging from the dependence on customers $[3,58]$.

Third, inter-functional coordination refers to the coordinated utilization of firm resources for creating superior value for target customers [59]. A culture of resource sharing and a willingness to work together among the functional units within a firm can play an important role in improving the firm's capability to exploit the resources for servitization well $[3,17]$. All functional units within a firm work jointly to accommodate the transition, assess the service demand, and produce any and all types of services timely and efficiently. Thus, we propose:

Hypothesis 2a (H2a). Market orientation has a positive effect on basic service provision.

Hypothesis $\mathbf{2 b}(\mathbf{H} \mathbf{2 b})$. Market orientation has a positive effect on advanced service provision.

There exist differences between TO and MO: the former underscores ideas that use the most advanced technologies, whereas the latter reflects the firm's philosophy on how to interact with the market [45]. Therefore, we argue that they would carry different implications for servitization.

For services supporting the material product (BAS), the focus is the product, and the predominant variables of the expanded marketing mix are the physical evidence and the process [39]. To succeed in this category, the greatest challenge for the manufacturer is to meet the customers' basic expectations in the most cost-efficient manner, sometimes using highly standardized services [21,43]. Therefore, it is important for the manufacturer to master specific technical expertise that concerns the product and that could improve the physical evidence and process to install and maintain basic product function in an 
efficient and effective manner. TO would allow them to redesign equipment, components, or processes, optimizing the costs and efficiency of BAS production and delivery. On the contrary, the intensity of the relationship (with the competitor, the customer, and among functional units) is less emphasized in the case of BAS [26]. The same services could be offered to different customers through standard interface, and an over-emphasis on MO would raise the costs of BAS. Thus, we propose:

Hypothesis 3a (H3a). The effect of technology orientation on basic service provision is stronger than that of market orientation.

In the case of services supporting the customer's action in relation to the manufacture's products (ADS), the focus is the customer and the predominant variable of the expanded marketing mix is people [39]. Compared with BAS, ADS are associated with higher levels of differentiating power $[7,33,39]$, customer intimacy, and customization $[1,60]$, as well as higher levels of potential risks $[6,26,38]$.

A manufacturer that pays greater attention to competitors is more likely to adopt ADS as a differentiation strategy to stand out in the market. ADS are co-produced with the customers who are involved as operant resources to obtain a specific and difficult-to-imitate value $[13,61]$. Thus, by providing ADS, the manufacturer is given a distinctive strength and competitive advantage against its competitors. Secondly, emphasis on customer focus leads to an increased understanding of unique customer needs and the development of closer customer relationships [46], which are both key for ADS. These resources are heterogeneous and highly specific to each customer, and can be leveraged to offer ADS to support the customer's business. With enhanced understanding and interaction, for example, the manufacturer could provide consulting on the efficient operation of the customer's processes, or even manage the processes on behalf of the customer. Moreover, a stronger relationship with and greater trust in the manufacturer would facilitate the customer's purchase of higher-value and higher-risk services such as ADS [26]. Finally, the development and delivery of non-standard ADS are associated with more complexity and uncertainty, which, to be dealt with, need more intense collaborations among the functional departments within a firm [38].

In contrast, constrained by its current repertoire, the technology-oriented manufacturer tends to focus its attention on technologies in the manufacturing field and may not transcend beyond what a typical manufacturer knows [62]. Confined by the traditional product-based thinking, service development in a manufacturer with high levels of TO is often driven by technology push, while customer preferences, which are especially indispensable for ADS, may not be adequately reflected [1]. Therefore, we suggest that TO has certain limitations in supporting ADS. Thus:

Hypothesis $\mathbf{3 b} \mathbf{( H 3 b )}$. The effect of market orientation on advanced service provision is stronger than that of technology orientation.

As mentioned above, high degrees of TO may blind the firm into the erroneous belief of technological superiority, but make it underestimate the importance of market demand which is, perhaps, only attended to by the marketing department in such a firm $[47,63]$. Nevertheless, when TO is combined with MO, more resources would be spent on the ongoing monitoring of the customer's needs and market conditions, as well as the organization-wide dissemination of and responsiveness to the market intelligence [54], whereby the technology-oriented manufacturing firm can adapt to the markets, and offer product-service bundles that appeal to the customers' needs or tastes with excellent technologies $[30,54]$.

On the other hand, MO could lead to a plethora of substitution possibilities if the competitors implement the same philosophy [64]. However, a technology push strategy helps establish barriers to competition, thereby enhancing the success rate of the servitization transition. Additionally, technologies can be employed to improve the firm's ability to 
collect, communicate and utilize market intelligence [46,65], develop new technical solutions and satisfy customer needs [29], and enhance traditional market research methods to unearth latent customer needs [66,67].

In sum, we suggest that $\mathrm{TO}$ and $\mathrm{MO}$ are complementary for servitization, in that the juxtaposition of a technology pursuit with a market-oriented culture contributes significantly to successful service provision. Thus, we propose:

Hypothesis 4a (H4a). Technology orientation and market orientation have a positive joint effect on basic service provision.

Hypothesis $4 \mathbf{b} \mathbf{( H 4 b ) . ~ T e c h n o l o g y ~ o r i e n t a t i o n ~ a n d ~ m a r k e t ~ o r i e n t a t i o n ~ h a v e ~ a ~ p o s i t i v e ~ j o i n t ~ e f f e c t ~}$ on advanced service provision.

\subsection{Servitization and Performance}

Empirical studies have raised questions about the performance implications of servitization, revealing the neutral or negative impacts of service offerings on manufacturing firms, as opposed to the positive effects claimed in most servitization literature $[15,26]$. One of the reasons for these inconsistent results is that the effects of servitization might be dependent on the types of service offerings and the specific conditions of the firm. Following this line of reasoning, we attempt to examine whether the firm size, a distinctive feature of the firm, plays a contingent role on the performance effects of BAS and ADS. Size has been considered an important condition that might moderate the impact of servitization and shape the choice related to servitization in previous research $[21,32]$.

BAS could help firms gain insights about product functionality and use [32], which thereby reinforces the firms' core product competence, makes the products easier to use, enables product sales, and establishes the firms' reputation as competent providers [43]. Those benefits are valuable for small firms, helping them survive the competition in the market. For example, it has been validated that starting to sell services has a positive impact on the profitability, employment, sales, and production of goods for small businesses [21]. BAS also serve as an important source of revenue in small firms. Additionally, adopting BAS allows for an incremental transition to services and a limited number of modifications, thus easing the burden that servitization may cause on small firms. Therefore, providing basic services is capable of producing positive results for firms with resource and managerial restrictions. On the other hand, pursuing ADS-related opportunities entails higher risks and more intense resource requirements for the manufacturer [32], which is likely to increase the possibility of managerial mistakes in the design and implementation of ADS [1]. For example, a radical change incurred by ADS and the allocation of resources among more independent business may provoke organizational conflicts, or engaging in different businesses simultaneously may give rise to the loss of strategic focus [12]. These problems would be more severe for small firms, as they often lack the skills or slack resources necessary for dealing with such increased uncertainties and demands.

In contrast, BAS are a "must have", and are often given away for free in large firms [43]. They are utilized to sustain these firms' positions, but have little contribution to improving their performance further. By contrast, ADS provide significant differentiation advantages in the market, and improve customer retention by increasing switch costs and customer satisfaction [43]. Large firms can charge premium prices as a result of providing these services, leading to a higher sales margin potential than their competitors. On the other hand, the costs and challenges of providing ADS are higher than BAS [32]. ADS provision involves significant changes or even a business model reconfiguration [32] and is more knowledge- and people-intensive $[7,26]$. For example, a separate service unit may be needed [68]. Large firms have adequate resources and capabilities to respond to the threats incurred by ADS and deal with these radical transitions, thus alleviating the negative impact that ADS would produce on firm performance. Overall, large firms have the potential to seize the greater financial, strategic, and marketing opportunities provided by ADS and turn them into real benefits [18]. 
Hypothesis 5a (H5a). The effect of basic service provision on performance is stronger than that of advanced service provision in small firms.

Hypothesis $\mathbf{5 b} \mathbf{b} \mathbf{H} \mathbf{5 b})$. The effect of advanced service provision on performance is stronger than that of basic service provision in large firms.

Based on the above argument, we present a research framework in Figure 1, which summarizes all the relationships hypothesized in this paper.

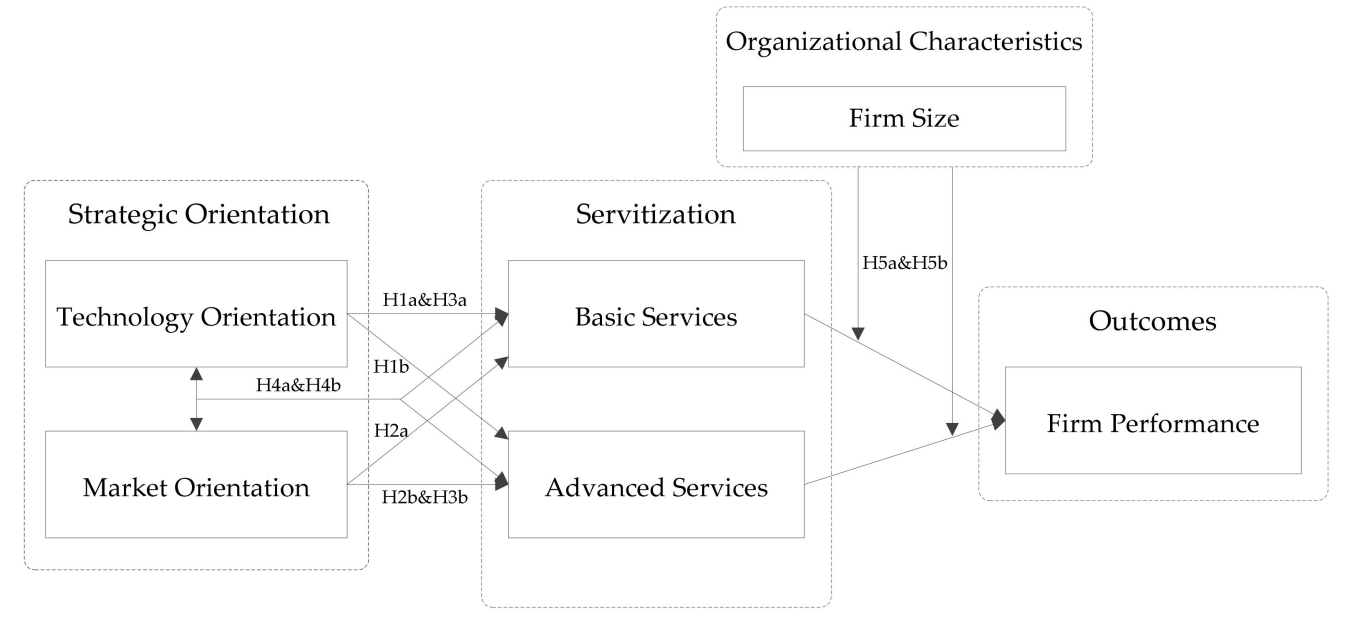

Figure 1. Research framework.

\section{Methods}

\subsection{Data Collection}

The focus of this study is the servitization of manufacturing firms, so we conducted the survey covering manufacturers from industries including the electronics, mechanical, and automotive industries in China from June 2019 to February 2020. There has been a rapid development in the manufacturing industry in China, based on its comparative advantage of production factors endowment [69]. However, the increasing costs of production factors as well as the problems of resource shortage and environment deterioration have been standing in the way of further development for China's manufacturers [69-71]. The Chinese government issued the "Made in China 2025" initiative, which aims to transform China from a manufacturing giant into a worldwide manufacturing power driven by innovation and emphasizing quality over quantity [72]. One of the development orientations prescribed in "Made in China 2025" is servitization, which is believed to be not only an accommodation to the global trend of moving forward to a service economy but also a viable approach to optimizing the industrial structure and moving up the value chain from low-end to high-end for China's manufacturing industry. Compared with developed countries, the servitization of manufacturing in China is still at a low level; nevertheless, an increase in the awareness and adoption of servitization is occurring in China, causing wide variations of servitization levels across firms. Thus, it is suitable to test our conceptual framework in China.

For the survey, we selected a random sample of 500 firms in Xi'an, Tianjin, Beijing, and the Yangtze River Delta region of China. We contacted these firms through emails or telephone calls before the survey to confirm their approval for participation and to identify the key respondents, and then distributed the questionnaires through site visits and e-mails to them. Follow-up calls and mailings were made 2 weeks later to improve the effective response rate. We received 262 replies after three reminders, of which 210 were complete and satisfactory, accounting for a $42.0 \%$ response rate. All of the informants were middle or senior managers with more than 2 years of work experience in current positions and sufficient knowledge to answer our questionnaire. The mean of a 5-point Likert scale item 
that indicates the extent of the respondent's knowledge about our research content is 4.45 (S.D. $=0.40)$.

\subsection{Measures}

Established multi-item scales, modified to our settings, were employed to operationalize all the constructs using a seven-point Likert scale ranging from 1 (strongly disagree) to 7 (strongly agree), except for firm size and firm age. We used the translation and back-translation technique to ensure the conceptual equivalence of the questionnaire. Semistructured and in-depth interviews were also conducted with 10 senior managers for instrument validity. After that, we revised a few items that were considered ambiguous or inaccurate. A pilot test was then conducted with 20 respondents, on the basis of which we finalized the questionnaire. Details of the constructs and the operationalizations are provided in Appendix A.

Following Guo and Cao [73] and Nadkarni and Narayanan [74], firm performance relative to the competitors was assessed by five accounting-based items. We developed the measures of servitization based on Eggert et al. [7] and Sousa and da Silveira [26]. BAS were measured by five items, reflecting the degree to which services aiming to set up and maintain basic product functionality were provided, while ADS were measured by six items, reflecting the extent to which services that co-create value with the customers considering their unique requirements were provided.

Technology orientation was measured with four items that were modified from Antioco et al. [16], Zhou et al. [45], and Tsou et al. [46], reflecting the firm's inclination to acquire and use advanced technologies. Based on Kumar et al. [75], we operationalized market orientation as a second-order construct focusing on three dimensions: customer orientation (five items), competitor orientation (four items), and inter-functional coordination (four items). As for firm size (FS), the respondents were asked to indicate the number of full-time employees in their firms, based on six options: (1) less than 100; (2) 100-300; (3) 301-1000; (4) 1001-2000; (5) 2001-5000; (6) more than 5000.

We also controlled for several variables that could possibly affect servitization and performance. Firm age (FA) was measured as the number of years since the firm's establishment $[14,73]$. Supplier integration reflected the level of long-term agreements with key suppliers [3]. Strategic flexibility captured the range of uses of the resources as well as the costs and/or time of switching from one use of a resource to an alternative one [76]. Environmental uncertainty referred to the extent of demand volatility and industry clockspeed [77].

\subsection{Bias Check}

We checked the non-response bias by comparing the responses of early and late waves of returned questionnaires in terms of firm attributes, such as industry, size, and age. The $t$-tests did not yield any significant difference (see Appendix B). Therefore, non-response bias is not a significant concern in our study.

In order to minimize the self-satisfaction effect and ensure the validity of the respondents' answers, we maintained full anonymity for all informants throughout the survey process. We also followed the measures suggested by Fisher, and used more specific and less direct questioning [78]. On the cover page of the questionnaire, a detailed explanation of the study's purpose was provided. The respondents were informed that the survey was designed for research only and that there were no right or wrong answers to our questions, that they should answer the questions as honestly as possible. We also promised to provide the respondents with a summary of the results, if requested.

Maintaining full anonymity reduced the possibility of common method bias in advance. We also found that the single-factor structure fitted the data poorly in confirmatory factor analysis, which suggested that the common method bias did not appear to significantly influence the findings. 


\section{Results}

\subsection{Demographic Profile}

Table 1 shows the descriptive statistics of sample firms along their major traits and informant profiles.

Table 1. Demographic profile of sample firms and respondents.

\begin{tabular}{lc}
\hline \multicolumn{1}{c}{ Characteristics of Sample Firms and Respondents } & \\
\hline Firm Age & 11.38 years \\
\hline Firm Size (Number of Employees) & Frequency \\
Less than 100 & $10.0 \%$ \\
$100-300$ & $41.9 \%$ \\
$301-1000$ & $25.7 \%$ \\
$1001-2000$ & $15.2 \%$ \\
2001-5000 & $3.4 \%$ \\
More than 5000 & $3.8 \%$ \\
\hline Industry Type & Frequency \\
Automotive & $14.8 \%$ \\
Electronics & $20.0 \%$ \\
Electrical & $15.2 \%$ \\
Mechanical & $17.1 \%$ \\
Textile & $10.5 \%$ \\
Pharmaceutical & $11.0 \%$ \\
Chemicals & $11.4 \%$ \\
\hline Type of Ownership & Frequency \\
State-owned & $10.0 \%$ \\
Joint venture & $27.6 \%$ \\
Limited companies & $15.2 \%$ \\
Private & $43.8 \%$ \\
Others & $3.4 \%$ \\
\hline Tenure of the Respondents & 3.36 years \\
\hline Job Position of the Respondents & Frequency \\
President/CEO & $6.7 \%$ \\
Vice President & $21.9 \%$ \\
General Manager & $39.5 \%$ \\
Middle Manager & $31.9 \%$ \\
\hline & \\
\hline & \\
\hline
\end{tabular}

\subsection{Measure Validation}

Table 2 reports the validity assessments of questionnaire items. As shown in Table 2, Cronbach's alpha for each multi-item construct is over 0.8 , showing high internal consistency. The composite reliability (CR) of each construct measure exceeds the 0.8 threshold, and all average variances extracted (AVE) are greater than $0.6[79,80]$.

In terms of confirmatory factor analysis, a second-order model conceptualizing market orientation as a higher-order factor and the three dimensions (i.e., customer orientation, competitor orientation, and inter-functional coordination) as the first-order factors was firstly estimated, with fairly acceptable goodness-of-fit indices (CFI $=0.97$; GFI $=0.92$; RMSEA $=0.07$ ), and with all the first- and second-order factor loadings being statistically significant. For the remaining multi-item scales, a seven-factor model was estimated. The results $(\mathrm{CFI}=0.94$; GFI $=0.83$; RMSEA $=0.06)$ indicated a good fit with the data. The statistically significant item loadings provided additional evidence for convergent validity. Overall, these measures all indicate good convergent validity and reliability.

The discriminant validity of the measures was assessed following Fornell and Larcker [80]. The squared correlation between each pair of constructs was less than the AVE for each individual construct, which suggested adequate discriminant validity. 
Table 2. Construct reliability and validity.

\begin{tabular}{|c|c|c|c|c|c|}
\hline Constructs & Scale Items & Factor Loadings & Alpha & CR & AVE \\
\hline \multirow{5}{*}{$\begin{array}{l}\text { Firm performance } \\
\text { (FP) }\end{array}$} & FP1 & 0.87 & 0.91 & 0.93 & 0.73 \\
\hline & FP2 & 0.79 & & & \\
\hline & FP3 & 0.88 & & & \\
\hline & $\mathrm{FP} 4$ & 0.89 & & & \\
\hline & FP5 & 0.84 & & & \\
\hline \multirow{5}{*}{$\begin{array}{l}\text { Basic services } \\
\text { (BAS) }\end{array}$} & BAS1 & 0.80 & 0.84 & 0.89 & 0.62 \\
\hline & BAS2 & 0.80 & & & \\
\hline & BAS3 & 0.84 & & & \\
\hline & BAS4 & 0.84 & & & \\
\hline & BAS5 & 0.65 & & & \\
\hline \multirow{6}{*}{$\begin{array}{l}\text { Advanced services } \\
\text { (ADS) }\end{array}$} & ADS1 & 0.85 & 0.93 & 0.92 & 0.73 \\
\hline & ADS2 & 0.87 & & & \\
\hline & ADS3 & 0.82 & & & \\
\hline & ADS4 & 0.83 & & & \\
\hline & ADS5 & 0.89 & & & \\
\hline & ADS6 & 0.88 & & & \\
\hline \multirow{4}{*}{$\begin{array}{l}\text { Technology orientation } \\
\text { (TO) }\end{array}$} & TO1 & 0.86 & 0.91 & 0.94 & 0.80 \\
\hline & TO2 & 0.94 & & & \\
\hline & TO3 & 0.86 & & & \\
\hline & TO4 & 0.92 & & & \\
\hline \multirow{5}{*}{$\begin{array}{l}\text { Customer orientation } \\
\text { (CUSO) }\end{array}$} & CUSO1 & 0.86 & 0.87 & 0.91 & 0.67 \\
\hline & CUSO2 & 0.84 & & & \\
\hline & CUSO3 & 0.84 & & & \\
\hline & CUSO4 & 0.73 & & & \\
\hline & CUSO5 & 0.81 & & & \\
\hline \multirow{4}{*}{$\begin{array}{l}\text { Competitor orientation } \\
\text { (COMO) }\end{array}$} & COMO1 & 0.82 & 0.88 & 0.92 & 0.74 \\
\hline & COMO2 & 0.86 & & & \\
\hline & COMO3 & 0.89 & & & \\
\hline & $\mathrm{COMO} 4$ & 0.87 & & & \\
\hline \multirow{4}{*}{$\begin{array}{l}\text { Inter-functional } \\
\text { coordination } \\
\text { (IFC) }\end{array}$} & IFC1 & 0.89 & 0.90 & 0.93 & 0.78 \\
\hline & IFC2 & 0.91 & & & \\
\hline & IFC3 & 0.92 & & & \\
\hline & IFC4 & 0.81 & & & \\
\hline \multirow{3}{*}{ Supplier integration (SI) } & SI1 & 0.90 & 0.92 & 0.95 & 0.86 \\
\hline & SI2 & 0.96 & & & \\
\hline & SI3 & 0.92 & & & \\
\hline \multirow{5}{*}{$\begin{array}{l}\text { Strategic flexibility } \\
\text { (SF) }\end{array}$} & SF1 & 0.90 & 0.94 & 0.96 & 0.82 \\
\hline & SF2 & 0.94 & & & \\
\hline & SF3 & 0.93 & & & \\
\hline & SF4 & 0.87 & & & \\
\hline & SF5 & 0.88 & & & \\
\hline \multirow{3}{*}{$\begin{array}{l}\text { Environmental uncertainty } \\
\text { (EU) }\end{array}$} & EU1 & 0.92 & 0.90 & 0.94 & 0.85 \\
\hline & EU2 & 0.95 & & & \\
\hline & EU3 & 0.89 & & & \\
\hline
\end{tabular}

\subsection{Analysis and Results}

The descriptive statistics and correlation matrix are presented in Table 3.

To test hypotheses 1 to 4 , pertaining to the relationship between strategic orientation and servitization, we used hierarchical regressions. The standardized results are summarized in Table 4.

H1a and H1b consider the effects of TO on BAS and ADS. Model 3 and Model 6, in Table 4 , show that TO has significant effects on both BAS $(\beta=0.264, p<0.01)$ and ADS ( $\beta=0.131, p<0.05)$, thus supporting H1a and H1b. Similarly, as shown in Model 3 and 
Model 6, significant positive relationships are found between MO and BAS ( $\beta=0.190$, $p<0.05)$, as well as between MO and ADS ( $\beta=0.661, p<0.001)$; thus, H2a and H2b, concerning the effects of $\mathrm{MO}$, are supported.

Table 3. Descriptive statistics and correlations.

\begin{tabular}{|c|c|c|c|c|c|c|c|c|c|c|c|c|}
\hline Variable & 1 & 2 & 3 & 4 & 5 & 6 & 7 & 8 & 9 & 10 & 11 & 12 \\
\hline 1. FP & & & & & & & & & & & & \\
\hline 2. BAS & $0.25 * *$ & & & & & & & & & & & \\
\hline 3. ADS & $0.32 * *$ & $0.36^{* *}$ & & & & & & & & & & \\
\hline 4. TO & $0.45^{* *}$ & $0.35^{* *}$ & $0.48^{* *}$ & & & & & & & & & \\
\hline 5. CUSO & $0.27 * *$ & $0.35^{* *}$ & $0.56^{* *}$ & $0.49^{* *}$ & & & & & & & & \\
\hline 6. $\mathrm{COMO}$ & $0.35^{* *}$ & $0.29 * *$ & $0.67 * *$ & $0.55^{* *}$ & $0.57^{* *}$ & & & & & & & \\
\hline 7. IFC & $0.42 * *$ & $0.21^{* *}$ & $0.63 * *$ & $0.51^{* *}$ & $0.63^{* *}$ & $0.77 * *$ & & & & & & \\
\hline 8. FS & 0.06 & 0.03 & 0.08 & 0.09 & 0.04 & 0.06 & 0.02 & & & & & \\
\hline 9. FA & $-0.14 *$ & 0.09 & 0.01 & -0.02 & -0.04 & -0.07 & $-0.14 *$ & $0.37^{* *}$ & & & & \\
\hline 10. SI & -0.10 & $0.18 *$ & 0.01 & 0.10 & 0.14 * & 0.04 & -0.01 & $0.17^{*}$ & 0.12 & & & \\
\hline 11. SF & 0.10 & 0.09 & $0.23 * *$ & 0.13 & $0.15^{*}$ & $0.26 * *$ & $0.24^{* *}$ & -0.06 & -0.05 & $0.18^{* *}$ & & \\
\hline 12. EU & -0.17 * & -0.02 & -0.06 & 0.02 & -0.01 & 0.01 & -0.06 & -0.16 & 0.06 & $0.17^{*}$ & $0.16^{*}$ & \\
\hline Mean & 5.55 & 5.49 & 4.39 & 5.78 & 6.00 & 5.67 & 5.56 & 2.71 & 11.38 & 5.46 & 4.25 & 4.61 \\
\hline S.D. & 0.87 & 0.83 & 1.06 & 0.90 & 0.77 & 0.94 & 1.02 & 1.17 & 6.27 & 1.15 & 1.39 & 1.28 \\
\hline
\end{tabular}

Table 4. Hierarchical regressions results for servitization.

\begin{tabular}{|c|c|c|c|c|c|c|}
\hline \multirow{2}{*}{ Variables } & \multicolumn{3}{|c|}{ Basic Service Provision (BAS) } & \multicolumn{3}{|c|}{ Advanced Service Provision (ADS) } \\
\hline & Model 1 & Model 2 & Model 3 & Model 4 & Model 5 & Model 6 \\
\hline \multicolumn{7}{|l|}{ Control variables } \\
\hline Firm age & $\begin{array}{c}0.073 \\
(0.009)\end{array}$ & $\begin{array}{c}0.094 \\
(0.009)\end{array}$ & $\begin{array}{c}0.092 \\
(0.009)\end{array}$ & $\begin{array}{c}0.032 \\
(0.012)\end{array}$ & $\begin{array}{l}0.091^{+} \\
(0.008)\end{array}$ & $\begin{array}{l}0.088^{+} \\
(0.008)\end{array}$ \\
\hline Supplier integration & 0.167 * & 0.140 * & 0.141 * & $\begin{array}{l}-0.022 \\
(0.065)\end{array}$ & $\begin{array}{l}-0.054 \\
(0.047)\end{array}$ & $\begin{array}{l}-0.051 \\
(0.046)\end{array}$ \\
\hline Strategic flexibility & $\begin{array}{c}0.069 \\
(0.042)\end{array}$ & $\begin{array}{c}0.001 \\
(0.040)\end{array}$ & $\begin{array}{c}0.005 \\
(0.040)\end{array}$ & $\begin{array}{c}0.254 * * * \\
(0.053)\end{array}$ & $\begin{array}{c}0.084 \\
(0.039)\end{array}$ & $\begin{array}{l}0.091^{+} \\
(0.039)\end{array}$ \\
\hline Environmental uncertainty & $\begin{array}{c}-0.065 \\
(0.045)\end{array}$ & $\begin{array}{c}-0.052 \\
(0.042)\end{array}$ & $\begin{array}{l}-0.046 \\
(0.042)\end{array}$ & $\begin{array}{c}-0.094 \\
(0.057)\end{array}$ & $\begin{array}{c}-0.052 \\
(0.041)\end{array}$ & $\begin{array}{l}-0.045 \\
(0.041)\end{array}$ \\
\hline \multicolumn{7}{|l|}{ Direct effects } \\
\hline Technology orientation (TO) & & $\begin{array}{c}0.241 * * \\
(0.073)\end{array}$ & $\begin{array}{c}0.264^{* *} \\
(0.075)\end{array}$ & & $\begin{array}{l}0.102^{+} \\
(0.071)\end{array}$ & $\begin{array}{l}0.131 * \\
(0.072)\end{array}$ \\
\hline Market orientation (MO) & & $\begin{array}{l}0.170 * \\
(0.084)\end{array}$ & $\begin{array}{l}0.190 * \\
(0.085)\end{array}$ & & $\begin{array}{c}0.637 * * * \\
(0.082)\end{array}$ & $\begin{array}{c}0.661 * * * \\
(0.083)\end{array}$ \\
\hline \multicolumn{7}{|l|}{ Interaction effects } \\
\hline $\mathrm{TO} \times \mathrm{MO}$ & & & $\begin{array}{c}0.087 \\
(0.058)\end{array}$ & & & $\begin{array}{l}0.110 * \\
(0.057)\end{array}$ \\
\hline $\operatorname{Adj} R^{2}$ & 0.024 & 0.147 & 0.149 & 0.046 & 0.507 & 0.515 \\
\hline $\mathrm{F}$ & $2.305+$ & $7.009 * * *$ & $6.232 * * *$ & $3.546 * *$ & $36.854^{* * *}$ & $32.668^{* * *}$ \\
\hline
\end{tabular}

Note: ${ }^{* * *} p<0.001,{ }^{* *} p<0.01,{ }^{*} p<0.05,{ }^{+} p<0.1$.

We ran the $t$-tests to examine the relative power of $\mathrm{TO}$ and $\mathrm{MO}$. The difference between the coefficients of $\mathrm{TO}$ and $\mathrm{MO}$, with regards to BAS, is insignificant $(t=0.34, p=0.73$ ), while the coefficient of $\mathrm{MO}$ on ADS is larger that of $\mathrm{TO}$, and the difference is significant $(t=5.37$, $p<0.001)$. These results indicate that TO and MO are equally important for BAS provision, yet $\mathrm{MO}$ is statistically stronger in supporting ADS than $\mathrm{TO}$, consequently rejecting $\mathrm{H} 3 \mathrm{a}$, but supporting $\mathrm{H} 3 \mathrm{~b}$.

With respect to $\mathrm{H} 4 \mathrm{a}$ and $\mathrm{H} 4 \mathrm{~b}$, we constituted an interaction term between $\mathrm{TO}$ and $\mathrm{MO}$, and examined its effects on BAS and ADS. As shown in Model 3 and Model 6, the interaction between TO and MO is not significant in relation to BAS $(\beta=0.087, p=0.226)$, but is significantly related to $\operatorname{ADS}(\beta=0.110, p<0.05)$. These results support H4b but not H4a.

To test $\mathrm{H} 5 \mathrm{a}$ and $\mathrm{H} 5 \mathrm{~b}$, we ran a subgroup regression analysis. The results are reported in Table 5. 
Table 5. Subgroup regression results for firm performance.

\begin{tabular}{|c|c|c|}
\hline & \multicolumn{2}{|c|}{ Firm Performance } \\
\hline & $\begin{array}{c}\text { Model } 7 \\
\text { Small Firms }(\leq 2)\end{array}$ & $\begin{array}{c}\text { Model } 8 \\
\text { Large Firms }(>2)\end{array}$ \\
\hline \multicolumn{3}{|l|}{ Control variables } \\
\hline Firm age & $\begin{array}{l}-0.063 \\
(0.015)\end{array}$ & $\begin{array}{c}-0.153^{+} \\
(0.012)\end{array}$ \\
\hline Supplier integration & $\begin{array}{l}-0.040 \\
(0.066)\end{array}$ & $\begin{array}{c}-0.168^{+} \\
(0.080)\end{array}$ \\
\hline Strategic flexibility & $\begin{array}{c}0.028 \\
(0.053)\end{array}$ & $\begin{array}{c}0.093 \\
(0.068)\end{array}$ \\
\hline Environmental uncertainty & $\begin{array}{l}-0.063 \\
(0.060)\end{array}$ & $\begin{array}{l}-0.198 * \\
(0.067)\end{array}$ \\
\hline \multicolumn{3}{|l|}{ Direct effects } \\
\hline Basic services (BAS) & $\begin{array}{l}0.284^{* *} \\
(0.099)\end{array}$ & $\begin{array}{c}0.091 \\
(0.109)\end{array}$ \\
\hline Advanced services (ADS) & $\begin{array}{c}0.147 \\
(0.073) \\
\end{array}$ & $\begin{array}{l}0.306 * * \\
(0.092)\end{array}$ \\
\hline $\operatorname{Adj} R^{2}$ & 0.086 & 0.220 \\
\hline $\mathrm{F}$ & $2.701 *$ & $5.693^{* * *}$ \\
\hline Sample size & 109 & 101 \\
\hline
\end{tabular}

We used the median split approach and partitioned the sample into two subsamples with lower (scale score $\leq$ the median score 2 ) and higher $(>2)$ levels of firm size separately. Model 7 shows that, in the small firms group, BAS have a significantly positive impact on firm performance $(\beta=0.284, p<0.01)$, while $\operatorname{ADS} \operatorname{do} \operatorname{not}(\beta=0.147, p=0.166)$. Thus, the effect of BAS on performance is stronger than that of ADS for small firms, supporting H5a. Similarly, Model 8 shows that, in the large firms group, ADS are positively and significantly related to firm performance $(\beta=0.306, p<0.01)$, while BAS are not $(\beta=0.091, p=0.335)$. $\mathrm{H} 5 \mathrm{~b}$ is thereby supported.

Table 6 summarizes the results of all the hypothesis tests.

Table 6. Results of the hypothesis tests.

\begin{tabular}{|c|c|c|}
\hline No & Hypothesis & Result \\
\hline H1a & $\begin{array}{c}\text { Technology orientation has a positive effect on basic } \\
\text { service provision. }\end{array}$ & Supported \\
\hline $\mathrm{H} 1 \mathrm{~b}$ & $\begin{array}{c}\text { Technology orientation has a positive effect on advanced } \\
\text { service provision. }\end{array}$ & Supported \\
\hline $\mathrm{H} 2 \mathrm{a}$ & Market orientation has a positive effect on basic service provision. & Supported \\
\hline $\mathrm{H} 2 \mathrm{~b}$ & $\begin{array}{c}\text { Market orientation has a positive effect on advanced } \\
\text { service provision. }\end{array}$ & Supported \\
\hline $\mathrm{H} 3 \mathrm{a}$ & $\begin{array}{l}\text { The effect of technology orientation on basic service provision is } \\
\text { stronger than that of market orientation. }\end{array}$ & Rejected \\
\hline $\mathrm{H} 3 \mathrm{~b}$ & $\begin{array}{l}\text { The effect of market orientation on advanced service provision is } \\
\text { stronger than that of technology orientation. }\end{array}$ & Supported \\
\hline $\mathrm{H} 4 \mathrm{a}$ & $\begin{array}{l}\text { Technology orientation and market orientation have a positive joint } \\
\text { effect on basic service provision. }\end{array}$ & Rejected \\
\hline $\mathrm{H} 4 \mathrm{~b}$ & $\begin{array}{l}\text { Technology orientation and market orientation have a positive joint } \\
\text { effect on advanced service provision. }\end{array}$ & Supported \\
\hline H5a & $\begin{array}{l}\text { The effect of basic service provision on performance is stronger } \\
\text { than that of advanced service provision in small firms. }\end{array}$ & Supported \\
\hline $\mathrm{H} 5 \mathrm{~b}$ & $\begin{array}{l}\text { The effect of advanced service provision on performance is stronger } \\
\text { than that of basic service provision in large firms. }\end{array}$ & Supported \\
\hline
\end{tabular}




\section{Discussion}

\subsection{Types of Servitization}

We contribute to the existing servitization literature by underscoring the need for distinguishing between different types of servitization. There is a growing consensus that the study of servitization needs to consider different service categories $[1,38,81]$, but servitization has generally been treated as a single construct, especially in empirical studies. Following Sousa and da Silveira [26], we identify two types of servitization from the perspective of the value co-creation processes associated with service offerings, i.e., basic (product-oriented) services and advanced (customer-oriented) services, each having unique contents and features, and disentangle their specific antecedents and performance implications. Our analysis reveals that BAS and ADS are two interrelated yet distinct constructs (Tables 2 and 3), and their requirements for strategic-level drivers and performance effects in specific contexts are somewhat different (Tables 4 and 5). This confirms that the challenges for servitization vary based on the types of service provision, and that certain resources and organizational characteristics are more suitable than others in a given situation, helping to reconcile some discrepant views in the servitization literature, due to the neglect of heterogeneity in services offered by the manufacturers, and providing empirical support to the servitization typology research.

\subsection{Strategic Orientation and Servitization}

Our findings extend the strategic choice theory by indicating that strategic orientation should be considered in the servitization context. This study makes an initial attempt to introduce the concepts of technology orientation and market orientation into the servitization literature and to assess their impacts on the different types of services that could be provided by manufacturers. Prior research on strategic orientation has mainly focused on its effects on product innovation or firm performance $[34,59,66]$. The positive effects of TO and $\mathrm{MO}$ on both types of service provision of manufacturers demonstrated by our research (Table 4) lend support to the value of strategic orientation in overcoming barriers to and fostering the addition of service design and delivery. Moreover, the findings about their relative power, with regards to ADS ( 0.131 vs. $0.661, p<0.001)$, provide more nuanced insights into the differences among alternative dimensions of strategic orientation. Under the guidance of $\mathrm{TO}$, focusing on advanced technologies, the service development in manufactures tends to prioritize efficiency, scale economies, and standardization, rather than flexibility, variety, and customization [12,82], limiting TO's potential in supporting ADS. Servitization research has identified technology-related resources as an important building block, but also cautioned against an over-emphasis on technology [43,83]. Our results corroborate this point of view by providing a better understanding of the pros and cons associated with TO in servitization. In contrast, extending the line of research that emphasizes the importance of customer orientation in servitization $[37,55]$, we suggest that $\mathrm{MO}$, focusing on customer and competitor, as well as on inter-functional coordination, is valuable for servitization, especially ADS. Servitization scholars were advised to move their attention away from the technology-related assets to the relational view approach $[20,23,83]$. We elaborate on this argument and show that the relational aspects with competitors, customers, and among the inner functional departments of the firm, are crucial for service infusion, especially for more advanced services.

Furthermore, we delve into the interaction of $\mathrm{TO}$ and $\mathrm{MO}$ in the context of servitization. While boosting BAS independently, these two organizational mindsets complement each other in creating an effective solution-provider organization that can deliver customized products and services (Table 4). Previous studies indicate that the combinative effects of different dimensions of strategic orientation are complex $[64,66,84]$. We have a limited understanding of how market and technology orientation together affect servitization transition. In the exploration of this issue, our findings reveal that there are different impacts of the interaction between $\mathrm{TO}$ and $\mathrm{MO}$ with regards to the different types of services, thus, to some extent, contributing to resolving the debate regarding the complementarity vs. 
substitutability between different dimensions of strategic orientation. These results are also consistent with the research interest in the role of capabilities to integrate technology development with customer value-understanding in servitization [20].

\subsection{Servitization and Performance}

This study examines the relationship between two types of servitization and firm performance in different conditions, and offers more clarity about the debated effects of servitization. Extending into service business endows the firm with benefits and advantages, but also is accompanied by considerable risks and burdens [1,18]. Some scholars have raised this question, about whether the successful implementation of specific service types requires the presence of different organizational characteristics $[18,85]$. We introduce the firm size as a contingency factor and suggest that the priority of the firm, between BAS and ADS, should be aligned with the capacity of the firm. BAS, rather than ADS, are beneficial for small firms, and ADS are advantageous for performance improvements in firms with certain positions and resources (Table 5). Previous research assumes that it is necessary to reach a critical mass of services to be profitable and that basic services are not sufficient for revenue $[7,12,86]$. Nevertheless, some studies have raised that whether this assumption holds may depend on specific contexts [32]. We enrich this line of study by revealing the effects of different types of servitization in firms with varying sizes. This enhances our understanding of the conditions for servitization practice as a viable strategy for performance improvement, responding to the call for the study of servitization contingencies $[38,81]$.

\subsection{Managerial Implications}

From a managerial perspective, our findings reveal the opportunities and challenges associated with the servitization transitions of manufacturing firms, and, thus, could enlighten the managers on decisions regarding servitization practice. Two major managerial implications follow from our analysis. First, distinguishing between different types of servitization and understanding their contingent performance effects could help the manufacturers design and develop service business more effectively and according to specific conditions. Our findings indicate that the firm size dictates the relative importance of BAS and ADS. For small firms with limited resources and capabilities, offering BAS along with products is suggested. Services that assist the customers in better-using the products could enable the small firms to increase their product sales and thereby survive in the market. ADS, by contrast, are more challenging and require more resources and organizational changes. They may often go beyond what small firms can afford and, thus, be counterproductive to their performance. Nevertheless, for large firms with more slack resources and a greater tolerance for risk, BAS are not sufficient for performance growth. To progress further, they have to develop novel ways of value proposition. Working with the customers to co-create value serves as a new source of growth and is worthy of pursuit by large manufacturers who are aspiring to advance their advantages. Emphasizing the wrong service type under the wrong condition can render the performance of the firm poor.

Second, our findings provide the firms with guidelines for how to achieve the right configuration of strategic orientations when responding to servitization issues. We have identified relevant strategic orientations that drive servitization. These orientations have been proven valuable in traditional manufacturing business, and they could also create favorable conditions for adding services to the offerings portfolio by ensuring the right resources and firm-specific behaviors. Furthermore, we find an alignment between strategic orientation dimensions and servitization types. Manufactures who aim to transform to the service business must appreciate the importance of allocating resources to pursue the effective (hence appropriate) $\mathrm{SO}(\mathrm{s})$ for the specific context. For firms that are about to provide product-related services, they can either implement a technology push strategy that dedicates resources to deepen their technological knowledge and to promote a proactive search for technological solutions throughout the firm, or carry out a market pull 
strategy that focuses attention on customers, competitors, and inter-functional coordination. However, for firms that endeavor to maintain their positions through BAS and differentiate themselves in the market through more advanced services, it is more critical to keep an eye on and respond to market intelligence, as opposed to technology intelligence. Regardless, a joint pursuit of advanced technologies and market knowledges would put the firm in a better position to provide ADS than an individual pursuit.

\section{Conclusions}

Since servitization has positive effects on the sustainable development of the micro enterprise, the macro economy, as well as the environment, it has been a topic of increased interest to both scholars and practitioners. However, debate continues about the performance implications of servitization, which may keep the manufactures from taking action in the transition. Building upon strategic choice theory and the servitization literature, we operationalize a model that connects strategic orientation, servitization, firm characteristics, and firm performance. By doing so, we provide a fine-grained understanding of the relationship among various dimensions of strategic orientation (i.e., TO and MO), different types of servitization (i.e., BAS and ADS), firm characteristics (i.e., firm size) and firm performance, and shed some new light on the servitization paradox. We find that both TO and MO are positively related to BAS and ADS provision. While these two strategic orientations equally affect BAS, MO is more important for ADS. Additionally, TO and MO function independently in facilitating BAS, yet complement each other in providing ADS. We also find the contingent effects of servitization on firm performance. BAS, rather than ADS, are beneficial for small firms, while the opposite is the case in large firms.

Despite its contributions, our study has several limitations. First, the cross-sectional design does not allow us to establish causality between the independent and dependent variables or to explore the dynamic evolution of servitization practice. Longitudinal designs are suggested for future research if feasible. Second, other dimensions of strategic orientation, such as entrepreneur orientation or learning orientation, could also play a role in servitization, and deserves theoretical or practical exploration. Third, there may be some contingent factors that could influence the effects of strategic orientation and other organizational characteristics that could influence the performance effects of servitization, providing interesting directions for future research.

Author Contributions: Conceptualization, Y.Z.; Methodology, Y.W.; Writing—original draft, Y.Z.; Writing-review and editing, Y.L. All authors have contributed to data collection. All authors have read and agreed to the published version of the manuscript.

Funding: This research was funded by the Humanities and Social Sciences Foundation of the Ministry of Education in China, grant number 17YJC630219, and the National Natural Science Foundation of China, grant numbers 71702046 and 71602145.

Conflicts of Interest: The authors declare no conflict of interest.

\section{Appendix A}

Table A1. Measurement items.

\begin{tabular}{cl}
\hline Constructs & \multicolumn{1}{c}{ Measurement Items } \\
\hline & FP1: Sales growth. \\
Firm performance & FP2: Market share growth. \\
(FP) $[73,74]$ & FP3: Profit growth. \\
& FP5: Return of assets. \\
& BAS1: Maintenance and repair of products sold to customers. \\
& BAS2: Installation/implementation services. \\
Basic services & BAS3: Spare parts/consumables provision for customers. \\
(BAS) $[7,26]$ & BAS4: Product documentation. \\
& BAS5: Product recycling and dismantling. \\
\hline
\end{tabular}


Table A1. Cont.

\begin{tabular}{|c|c|}
\hline Constructs & Measurement Items \\
\hline $\begin{array}{l}\text { Advanced services } \\
\text { (ADS) }[7,26]\end{array}$ & $\begin{array}{l}\text { ADS1: Rental/lease of products. } \\
\text { ADS2: Product modifications and customization. } \\
\text { ADS3: Help desk/customer support center. } \\
\text { ADS4: Training in using the products. } \\
\text { ADS5: Consultancy services. } \\
\text { ADS6: Outsourcing services. }\end{array}$ \\
\hline $\begin{array}{l}\text { Technology orientation } \\
\text { (TO) }[16,45,46]\end{array}$ & $\begin{array}{l}\text { TO1: Emphasize using sophisticated technologies. } \\
\text { TO2: Emphasize applying the latest technology. } \\
\text { TO3: Emphasize acquiring new technologies. } \\
\text { TO4: Emphasize adopting technology innovations. }\end{array}$ \\
\hline $\begin{array}{l}\text { Customer orientation } \\
\text { (CUSO) [75] }\end{array}$ & $\begin{array}{l}\text { CUSO1: Emphasize customer satisfaction. } \\
\text { CUSO2: Emphasize understanding customer needs. } \\
\text { CUSO3: Measure customer satisfaction frequently and systematically. } \\
\text { CUSO4: Increase customer value or reduce costs frequently. } \\
\text { CUSO5: Emphasize the high quality of products. }\end{array}$ \\
\hline $\begin{array}{l}\text { Competitor orientation } \\
\text { (COMO) [75] }\end{array}$ & $\begin{array}{l}\text { COMO1: Respond to competitors' actions rapidly. } \\
\text { COMO2: Share competitor's strategic information in the firm. } \\
\text { COMO3: Top managers discuss competitors' strength and strategies. } \\
\text { COMO4: Have competitive advantage in targeting customer. }\end{array}$ \\
\hline $\begin{array}{l}\text { Inter-functional coordination } \\
\text { (IFC) [75] }\end{array}$ & $\begin{array}{l}\text { IFC1: Share market information among functions efficiently. } \\
\text { IFC2: All functions contribute to customer value. } \\
\text { IFC3: All employees know market information. } \\
\text { IFC4: Marketing employees take part in new product development. }\end{array}$ \\
\hline Supplier integration (SI) [3] & $\begin{array}{l}\text { SI1: Share information with key suppliers. } \\
\text { SI2: Develop collaborative approaches with key suppliers. } \\
\text { SI3: Make decisions jointly with key suppliers. }\end{array}$ \\
\hline $\begin{array}{l}\text { Strategic flexibility } \\
\text { (SF) [76] }\end{array}$ & $\begin{array}{l}\text { SF1: Major resources can be applied to a large range of alternative uses. } \\
\text { SF2: Major resources can be switched from one use to an alternative one } \\
\text { with low difficulty. } \\
\text { SF3: Major resources can be switched from one use to an alternative one } \\
\text { in a short time. } \\
\text { SF4: Major resources can be switched from one use to an alternative one } \\
\text { with low costs. } \\
\text { SF5: Major resources can be allocated to develop, manufacture, and } \\
\text { deliver a diverse line of products. }\end{array}$ \\
\hline $\begin{array}{l}\text { Environmental uncertainty } \\
\text { (EU) [77] }\end{array}$ & $\begin{array}{l}\text { EU1: Extent of demand variability. } \\
\text { EU2: Rate of product replacement in the market. } \\
\text { EU3: Change rate of product technology. }\end{array}$ \\
\hline
\end{tabular}

\section{Appendix B}

Table A2. T-test results for non-response bias.

\begin{tabular}{cccccc}
\hline & \multicolumn{2}{c}{ Levene's Test } & \multicolumn{3}{c}{ T-Test } \\
\cline { 2 - 6 } & $\mathbf{F}$ & Sig. & $\mathbf{t}$ & $\mathbf{S i g}$. & Mean Difference \\
\hline Industry & 0.03 & 0.85 & 1.09 & 0.28 & 0.36 \\
Firm size & 1.55 & 0.22 & -0.29 & 0.77 & -0.06 \\
Firm age & 1.88 & 0.17 & 0.91 & 0.37 & 0.98 \\
Ownership & 0.20 & 0.66 & -0.43 & 0.67 & -0.08 \\
\hline
\end{tabular}

\section{References}

1. Benedettini, O.; Neely, A.; Swink, M. Why do servitized firms fail? A risk-based explanation. Int. J. Oper. Prod. Manag. 2015, 35, 946-979. [CrossRef]

2. Neely, A. Exploring the financial consequences of the servitization of manufacturing. Oper. Manag. Res. 2008, 1, 103-118. [CrossRef]

3. Shah, S.A.A.; Jajja, M.S.S.; Chatha, K.A.; Farooq, S. Servitization and supply chain integration: An empirical analysis. Int. J. Prod. Econ. 2020, 229, 107765. [CrossRef]

4. Baines, T.S.; Lightfoot, H.W.; Benedettini, O.; Kay, J.M. The servitization of manufacturing: A review of literature and reflection on future challenges. J. Manuf. Technol. Mana. 2009, 20, 547-567. [CrossRef] 
5. Vandermerwe, S.; Rada, J. Servitization of business: Adding value by adding services. Eur. Manag. J. 1988, 6, 314-324. [CrossRef]

6. $\quad$ Li, H.S.; Yang, Y.; Singh, P.; Sun, H.Y.; Tian, Y.Z. Servitization and performance: The moderating effect of supply chain integration. Prod. Plan. Control 2021, 1-18. [CrossRef]

7. Eggert, A.; Hogreve, J.; Ulaga, W.; Muenkhoff, E. Revenue and profit implications of industrial service strategies. J. Serv. Res. 2014, 17, 23-39. [CrossRef]

8. Gebauer, H.; Paiola, M.; Saccani, N.; Rapaccini, M. Digital servitization: Crossing the perspectives of digitization and servitization. Ind. Mark. Manag. 2021, 93, 382-388. [CrossRef]

9. Tukker, A. Product services for a resource-efficient and circular economy-A review. J. Clean. Prod. 2015, 97, 76-91. [CrossRef]

10. Seclen-Luna, J.P.; Moya-Fernandez, P.; Pereira, A. Exploring the effects of innovation strategies and size on manufacturing firms' productivity and environmental impact. Sustainability 2021, 13, 3289. [CrossRef]

11. Hao, Z.R.; Liu, C.G.; Goh, M. Determining the effects of lean production and servitization of manufacturing on sustainable performance. Sustain. Prod. Consump. 2021, 25, 374-389. [CrossRef]

12. Fang, E.; Palmatier, R.W.; Steenkamp, J.B.E.M. Effect of service transition strategies on firm value. J. Mark. 2008, 72, 1-14. [CrossRef]

13. Ambroise, L.; Prim-Allaz, I.; Teyssier, C. Financial performance of servitized manufacturing firms: A configuration issue between servitization strategies and customer-oriented organizational design. Ind. Mark. Manag. 2017, 71, 54-68. [CrossRef]

14. Punstein, A.M.; Gluckler, J. How small and medium sized firms walk the path to hybridity. Sustainability 2021, 13, 2511. [CrossRef]

15. Gebauer, H.; Fleisch, E.; Friedli, T. Overcoming the service paradox in manufacturing companies. Eur. Manag. J. 2005, 23, 14-26. [CrossRef]

16. Antioco, M.; Moenaert, R.K.; Lindgreen, A.; Wetzels, M.G.M. Organizational antecedents to and consequences of service business orientations in manufacturing companies. J. Acad. Mark. Sci. 2008, 36, 337-358. [CrossRef]

17. Visnjic Kastalli, I.; Van Looy, B. Servitization: Disentangling the impact of service business model innovation on manufacturing firm performance. J. Oper. Manag. 2013, 31, 169-180. [CrossRef]

18. Li, H.S.; Tian, G.Y.; Tian, Y.Z. Servitization: Its preferred organization and impact on firm performance. Hum. Syst. Manag. 2018, 37, 181-193. [CrossRef]

19. Lin, Y.; Luo, J.; Ieromonachou, P.; Rong, K.; Huang, L. Strategic orientation of servitization in manufacturing firms and its impacts on firm performance. Ind. Manag. Data. Syst. 2019, 119, 292-316. [CrossRef]

20. Huikkola, T.; Rabetino, R.; Kohtamaki, M.; Gebauer, H. Firm boundaries in servitization: Interplay and repositioning practices. Ind. Mark. Manag. 2020, 90, 90-105. [CrossRef]

21. Crozet, M.; Milet, E. Should everybody be in services? The effect of servitization on manufacturing firm performance. J. Econ. Manage. Strat. 2017, 26, 820-841. [CrossRef]

22. Kowalkowski, C.; Gebauer, H.; Kamp, B.; Parry, G. Servitization and deservitization: Overview, concepts, and definitions. Ind. Mark. Manag. 2017, 40, 4-10. [CrossRef]

23. Rondi, E.; De Massis, A.; Kraus, S. Servitization through open service innovation in family firms: Exploring the ability-willingness paradox. J. Bus. Res. 2021, 135, 436-444. [CrossRef]

24. Klein, S.P.; Spieth, P.; Heidenreich, S. Facilitating business model innovation: The influence of sustainability and the mediating role of strategic orientations. J. Prod. Innovat. Manag. 2021, 38, 271-288. [CrossRef]

25. Gebauer, H.; Fleisch, E. An investigation of the relationship between behavioral processes, motivation, investments in the service business and the service revenue. Ind. Mark. Manag. 2007, 36, 337-348. [CrossRef]

26. Sousa, R.; da Silveira, G.J.C. Capability antecedents and performance outcomes of servitization: Differences between basic and advanced services. Int. J. Oper. Prod. Manag. 2017, 37, 444-467. [CrossRef]

27. Gebauer, H.; Saul, C.J.; Haldimann, M.; Gustafsson, A. Organizational capabilities for pay-per-use services in product-oriented companies. Int. J. Prod. Econ. 2017, 192, 157-168. [CrossRef]

28. Spanjol, J.; Mühlmeier, S.; Tomczak, T. Strategic orientation and product innovation: Exploring a decompositional approach. J. Prod. Innovat. Manag. 2012, 29, 967-985. [CrossRef]

29. Gatignon, H.; Xuereb, J.M. Strategic orientation of the firm and new product performance. J. Mark. Res. 1997, 34, 77-90. [CrossRef]

30. Narver, J.C.; Slater, S.F. The effect of a market orientation on business profitability. J. Mark. 1990, 54, 20-35. [CrossRef]

31. Kozlowska, J. What influences the servitization process the most? A perspective of polish machinery manufacturers. Sustainability 2020, 12, 5056. [CrossRef]

32. Queiroz, S.A.B.; Mendes, G.H.S.; Silva, J.H.O. Servitization and performance: Impacts on small and medium enterprises. J. Bus. Ind. Mark. 2020, 35, 1237-1249. [CrossRef]

33. Eggert, A.; Hogreve, J.; Ulaga, W.; Muenkhoff, E. Industrial services, product innovations, and firm profitability: A multiple-group latent curve analysis. Ind. Mark. Manag. 2011, 40, 661-670. [CrossRef]

34. Yang, C.; Tang, G.Y.; Jin, J.F.; Xie, Q.H.; Li, J. CEOs' transformational leadership and product innovation performance: The roles of corporate entrepreneurship and technology orientation. J. Prod. Innovat. Manag. 2014, 31, 2-17. [CrossRef]

35. Tseng, C.H.; Chang, K.H.; Chen, H.W. Strategic orientation, environmental innovation capability, and environmental sustainability performance: The case of Taiwanese suppliers. Sustainability 2019, 11, 1127. [CrossRef]

36. Khanra, S.; Dhir, A.; Parida, V.; Kohtamaki, M. Servitization research: A review and bibliometric analysis of past achievements and future promises. J. Bus. Res. 2021, 131, 151-166. [CrossRef] 
37. Kohtamki, M.; Einola, S.; Rabetino, R. Exploring servitization through the paradox lens: Coping practices in servitization. Int. J. Prod. Econ. 2020, 226, 107619. [CrossRef]

38. Sousa, R.; da Silveira, G.J.C. The relationship between servitization and product customization strategies. Int. J. Oper. Prod. Manag. 2019, 39, 454-474. [CrossRef]

39. Mathieu, V. Product services: From a service supporting the product to a service supporting the client. J. Bus. Ind. Mark. 2001, 16, 39-61. [CrossRef]

40. Szász, L.; Demeter, K.; Boer, H.; Cheng, Y. Servitization of manufacturing: The effect of economic context. J. Manuf. Technol. Manag. 2017, 28, 1011-1034. [CrossRef]

41. Saccani, N.; Visintin, F.; Rapaccini, M. Investigating the linkages between service types and supplier relationships in servitized environments. Int. J. Prod. Econ. 2014, 149, 226-238. [CrossRef]

42. Wang, W.J.; Lai, K.H.; Shou, Y.Y. The impact of servitization on firm performance: A meta-analysis. Int. J. Oper. Prod. Manag. 2018, 38, 1562-1588. [CrossRef]

43. Ulaga, W.; Reinartz, W.J. Hybrid offerings: How manufacturing firms combine goods and services successfully. J. Mark. 2011, 75, 5-23. [CrossRef]

44. Yu, Y.; Li, M.; Li, X.; Zhao, J.L.; Zhao, D.T. Effects of entrepreneurship and IT fashion on SMEs' transformation toward cloud service through mediation of trust. Inform. Manag. 2017, 55, 245-257. [CrossRef]

45. Zhou, K.Z.; Yim, C.K.; Tse, D.K. The effects of strategic orientations on technology-and market-based breakthrough innovations. J. Mark. 2005, 69, 42-60. [CrossRef]

46. Tsou, H.T.; Chen, J.S.; Liao, W.H. Market and technology orientations for service delivery innovation: The link of innovative competence. J. Bus. Ind. Mark. 2014, 29, 499-513. [CrossRef]

47. Atuahene-Gima, K.; Ko, A. An empirical investigation of the effect of market orientation and entrepreneurship orientation alignment on product innovation. Organ. Sci. 2001, 12, 54-74. [CrossRef]

48. Paiola, M.; Gebauer, H. Internet of things technologies, digital servitization and business model innovation in BtoB manufacturing firms. Ind. Mark. Manag. 2020, 89, 245-264. [CrossRef]

49. Hurley, R.F.; Hult, G.T.M. Innovation, market orientation, and organizational learning: An integration and empirical examination. J. Mark. 1998, 62, 42-54. [CrossRef]

50. Visnjic, I.; Wiengarten, F.; Neely, A. Only the brave: Product innovation, service business model innovation, and their impact on performance. J. Prod. Innovat. Manag. 2016, 33, 36-52. [CrossRef]

51. Nordin, F.; Lindahl, I.; Brege, S. The applicability of integrated solutions offerings: Differential effects of product complexity. J. Relationship. Mark. 2013, 12, 59-78. [CrossRef]

52. Kindström, D.; Kowalkowski, C. Development of industrial service offerings: A process framework. J. Serv. Manag. 2009, 20, 156-172. [CrossRef]

53. Feng, C.; Patel, P.C.; Xiang, K.X. The well-trodden path: Complementing market and entrepreneurial orientation with a strategic emphasis to influence IPO survival in the United States. J. Bus. Res. 2020, 110, 370-385. [CrossRef]

54. Kohli, A.K.; Jaworski, B.J. Market orientation: The construct, research propositions, and managerial implications. J. Mark. 1990, 54, 1-18. [CrossRef]

55. Weigel, S.; Hadwich, K. Success factors of service networks in the context of servitization-Development and verification of an impact model. Ind. Mark. Manag. 2018, 74, 254-275. [CrossRef]

56. Green, M.H.; Davies, P.; Ng, I.C.L. Two strands of servitization: A thematic analysis of traditional and customer co-created servitization and future research directions. Int. J. Prod. Econ. 2017, 192, 40-53. [CrossRef]

57. Chen, J.S.; Kerr, D.; Tsang, S.S.; Sung, Y.C. Co-production of service innovations through dynamic capability enhancement. Serv. Ind. J. 2015, 35, 96-114. [CrossRef]

58. Windahl, C.; Lakemond, N. Developing integrated solutions: The importance of relationships within the network. Ind. Mark. Manag. 2006, 35, 806-818. [CrossRef]

59. Yang, Y.; Wang, Q.; Zhu, H.Y.; Wu, G.S. What are the effective strategic orientations for new product success under different environments? An empirical study of Chinese businesses. J. Prod. Innovat. Manag. 2012, 29, 166-179. [CrossRef]

60. Raddats, C.; Kowalkowski, C. A reconceptualization of manufacturers' service strategies. J. Bus. Bus. Mark. 2014, $21,19-43$. [CrossRef]

61. Tuli, K.R.; Kohli, A.K.; Bharadwaj, S.G. Rethinking customer solutions: From product bundles to relational processes. J. Mark. 2007, 71, 1-17. [CrossRef]

62. Morgan, T.; Anokhin, S.A.; Wincent, J. New service development by manufacturing firms: Effects of customer participation under environmental contingencies. J. Bus. Res. 2019, 104, 497-505. [CrossRef]

63. Hart, S.L. An integrative framework for strategy-making processes. Acad. Manag. Rev. 1992, 17, 327-351. [CrossRef]

64. Morgan, T.; Anokhin, S.; Kretinin, A.; Frishammar, J. The dark side of the entrepreneurial orientation and market orientation interplay. Int. Small. Bus. J. 2015, 33, 731-751. [CrossRef]

65. Bitner, M.J.; Brown, S.W.; Meuter, M.L. Technology infusion in service encounters. J. Acad. Mark. Sci. 2000, 28, 138-149. [CrossRef]

66. Gotteland, D.; Shock, J.; Sarin, S. Strategic orientations, marketing proactivity and firm market performance. Ind. Mark. Manag. 2020, 91, 610-620. [CrossRef] 
67. Narver, J.C.; Slater, S.F.; MacLachlan, D.L. Responsive and proactive market orientation and new-product success. J. Prod. Innovat. Manag. 2004, 21, 334-347. [CrossRef]

68. Oliva, R.; Kallenberg, R. Managing the transition from products to services. Int. J. Serv. Ind. Manag. 2003, 14, 160-172. [CrossRef]

69. Chen, W.; Chen, Y.Z.; Hao, Y.F.; Chen, S.L. Producer Services Openness and the Development of Servitization: The Perspective of Two-Way Openness. Discrete. Dyn. Nat. Soc. 2021, 2021, 8717130. [CrossRef]

70. Gao, J.; Yao, Y.L.; Zhu, V.C.Y.; Sun, L.Y.; Lin, L. Service-oriented manufacturing: A new product pattern and manufacturing paradigm. J. Intell. Manuf. 2011, 22, 435-446. [CrossRef]

71. Cui, R.X.; Wang, J.R.; Xue, Y.J.; Liang, H.G. Interorganizational learning, green knowledge integration capability and green innovation. Eur. J. Innov. Manag. 2021, 24, 1292-1314. [CrossRef]

72. Made in China 2025; China State Council: Beijing, China, 2015.

73. Guo, H.; Cao, Z. Strategic flexibility and SME performance in an emerging economy: A contingency perspective. J. Organ. Change. Manag. 2014, 27, 273-298. [CrossRef]

74. Nadkarni, S.; Narayanan, V.K. Strategic schemas, strategic flexibility, and firm performance: The moderating role of industry clockspeed. Strateg. Manag. J. 2007, 28, 243-270. [CrossRef]

75. Kumar, K.; Subramaniam, R.; Yauger, C. Examining the market orientation performance relationship: A context specific study. J. Manag. 1998, 24, 201-233. [CrossRef]

76. Wei, Z.; Yi, Y.; Guo, H. Organizational Learning Ambidexterity, Strategic Flexibility, and New Product Development. J. Prod. Innovat. Manag. 2014, 31, 832-847. [CrossRef]

77. Wei, H.L.; Wong, C.W.Y.; Lai, K.H. Linking inter-organizational trust with logistics information integration and partner cooperation under environmental uncertainty. Int. J. Prod. Econ. 2012, 139, 642-653. [CrossRef]

78. Fisher, R.J. Social desirability bias and the validity of indirect questioning. J. Consum. Res. 1993, 20, 303-315. [CrossRef]

79. Hair, J.F.; Hult, G.T.M., Jr.; Ringle, C.; Sarstedt, M. A Primer on Partial Least Squares Structural Equation Modeling (PLS-SEM); Sage Publications: Thousand Oaks, CA, USA, 2014.

80. Fornell, C.; Larcker, D.F. Evaluating structural equation models with unobservable variables and measurement error. J. Mark. Res. 1981, 18, 39-50. [CrossRef]

81. Baines, T.; Bigdeli, A.Z.; Bustinza, O.F.; Shi, V.G.; Baldwin, J.; Ridgway, K. Servitization: Revisiting the state-of-the-art and research priorities. Int. J. Oper. Prod. Manag. 2017, 37, 256-278. [CrossRef]

82. Kindström, D.; Kowalkowski, C.; Sandberg, E. Enabling service innovation: A dynamic capabilities approach. J. Bus. Res. 2013, 66, 1063-1073. [CrossRef]

83. Eloranta, V.; Turunen, T. Seeking competitive advantage with service infusion: A systematic literature review. J. Serv. Manag. 2015, 26, 394-425. [CrossRef]

84. Im, S.; Vorhies, D.W.; Kim, N.; Heiman, B. How knowledge management capabilities help leverage knowledge resources and strategic orientation for new product advantages in B-to-B high-technology firms. J. Bus. Bus. Mark. 2016, 23, 87-110. [CrossRef]

85. Böhm, E.; Eggert, A.; Thiesbrummel, C. Service transition: A viable option for manufacturing companies with deteriorating financial performance? Ind. Mark. Manag. 2017, 60, 101-111. [CrossRef]

86. Ruiz-Alba, J.L.; Soares, A.; Rodriguez-Molina, M.A. Servitization strategies from customers' perspective: The moderating role of co-creation. J. Bus. Ind. Mark. 2019, 34, 628-642. [CrossRef] 